\title{
Developing engineering students' engagement with Circular Economy practices
}

Ormazabal, Marta ${ }^{\text {; Jaca, Carmen }}{ }^{\text {a }}$, Prieto-Sandoval, Vanessa ${ }^{\text {a }}$, and Lleó, Álvaro ${ }^{\text {a }}$ ${ }^{a}$ Department of Industrial Management, Tecnun - University of Navarra, Spain

\begin{abstract}
The Circular Economy has become a topic of high interest for policy makers, scholars, and business managers because it is shown as a new paradigm to achieve the sustainability of our society. However, the main efforts in Circular Economy cannot be reduced to professional or experts' acts. Nevertheless, we consider that if we pretend to meet the current needs without compromising the ability of future generations to meet their own needs, we have to teach present generations the principles to achieve the economic, social and economic sustainability in the short and long term. This paper enhances the use of guided and official student clubs at the university to teach and engage engineering students with the Circular Economy practices.
\end{abstract}

Keywords: Higher education learning, circular economy, green day, sustainability, Sustainability education 


\section{Introduction}

Current consumption and growth patterns are leading society on a highly unsustainable path, which is increasingly damaging the ecosystem and endangering the provision of resources and ecosystem services (Robèrt et al., 2004). Today's linear industrial model implies a need for a model that uses less raw material and is more aligned with the cyclical nature of Earth. A concept that claims to provide such a model is Circular Economy (CE). Therefore, this concept can potentially address the sustainability challenge by reducing resource extraction and waste streams, and support businesses in moving towards sustainability. Adopting circular business models that seek to support the planet resilience could present an attractive win-win-win situation for society, the environment and the company itself. In the long-run, this transformation could offer an essential competitive advantage as CE claims to create more value from resources, support companies in meeting changing market requirements, lowering environmental costs, increasing consumer convenience and securing supplies (Preston, 2012).

Since the Agenda 21, an action plan for achieving the sustainable development, delivered at the Earth Summit in Rio de Janeiro in 1992, it has been globally accepted the education capacity to promote the sustainable development in people behaviors to address sustainable development issues (UN, 1992). Nonetheless, the literature about the integration of sustainability cocepts and circular economy in higher education and university curricula is still limited. Preston (2012) claims, school and university students are the ones that are going to be the innovators of the next decades, what means that university lecturers have to ensure to transmit the students the necessary knowledge about sustainability and circular economy so they will be able to implement in the near future the corresponding actions. An important initiative is being developed by the International Baccalaureate ${ }^{\circledR}$ (IB), a nonprofit educational foundation which offers respected programs of international education, has announced that they are collaborating with Ellen MacArthur Foundation to embed systems thinking and a circular economy perspective into the IB curriculum (IB, 2016). Moreover, universities have increased the offer of academic programs related to sustainability and environmental sciences like Delft University of Technology.For instance, a survey in the United States identified 840 degree-granting programs at 652 institutions that offer 1183 interdisciplinary environmental degrees (Vincent,2009).

Then, companies are responding to the schools and universities efforts, Goel (2005) enhanced that engineers awareness of environmental issues is an appreciated skill in Indian companies, over and beyond other skills such as social skills, specialized engineering proficiency or Project management skills. However, authors like Azapagic et al. have provide evidence of the low level knowledge and understanding of environmental and sustainability issues by engineering students from 21 universities based in Europe, North and South America, the Far East and Australia. Consequently, the objective of this research 
is to increase engineering students' engagement with Circular Economy as a valuable skill to act as a social agent in their further professional performance, from their activity in firms or governmental institutions. Moreover, this work contributes to existing knowledge in sustainability learning by providing a detailed caseof enginireng students who have learnt about circular economy with real and innovative actions out of the class room such as the design, organization, performance and the greenday assessment. Therefore, these kinds of experiences have a higher impact in the students' motivation and engagement (Blumenfeld et al., 1991).

\section{Method}

This research has been carried out with the students from the University of Navarra, particularly with the Engineering School (Tecnun) students. At Tecnun, different subjects are taught in which the environmental sustainability is treated, but it has been believed more effective that the students acquire the competencies through an activity that can be projected to the whole campus. In this way, Cardona \& García-Lombardía (2005) enhance that a learning activity is more effective if it is complemented with knowledge transmission, coaching, and training. Thus, real actions are more visualized and more people might be aware of the importance of sustainability. In order to link the activity to a topic of knowledge, the "Green Day" activity was developed within the Environmental Technology subject for the industrial management degree students and the industrial design students. This event was one of more than 30 academic events directly related to the environment and sustainability that took place at 2016 in the University of Navarra (in its four campuses of Pamplona, San Sebastián, Barcelona y Madrid).

The purpose of the Green Day was that students could become aware of what they caused to the environment. A total of 45 students decided to organize the Green Day. These students had one session about Circular Economy, so they could better understand the importance of taking care of the environment and this way it would be easier that they involve other students in this day. After the session, the students thought about possible activities to organize the Green Day. The list of activities that the student organizers had to prepare were the following ones: bicycles' paths, communication, sponsors, flea market and workshops. 


\section{Results}

\subsection{Bicycles}

The bicycles group (9 leaders) created three different routes from different parts of the city to come by bike. As for what that day is concerned, they divided themselves between the different points of departure and each one was responsible for being at the defined time in the place to wait for the rest of the people. Although they would have liked more people to participate, progress was made with respect to last year, achieving a group of 25 people without including the people who did not join the routes but arrived on their own by bicycle due to scheduling reasons (Figure 1). Along the way, they took photos and videos and they sent them to the communication team. To encourage this sustainable transport, the participants receive a ticket to participate in a raffle for a prize.
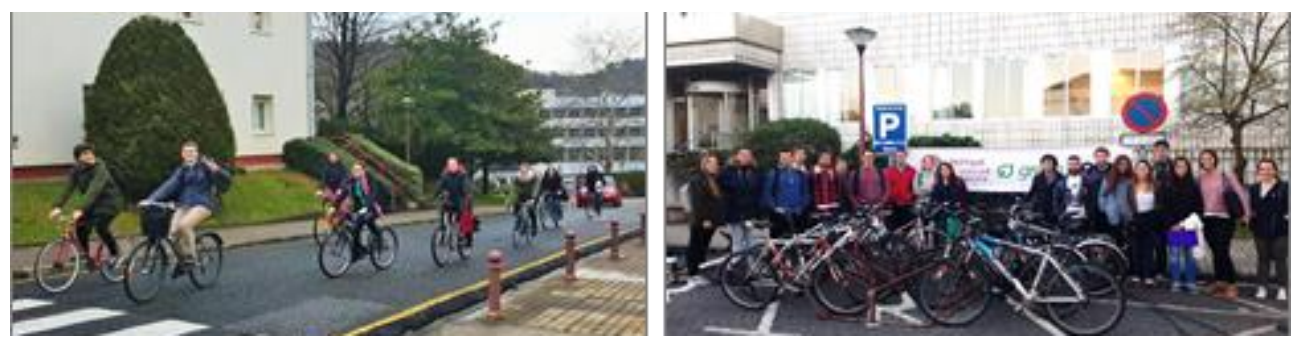

Figure 1. Students arriving at the university

\subsection{Communication}

The organizers (4 students) were in charged of communicating and the disseminating this event. In the first place, they made several posters related to that day in which the different activities and events were exposed. The posters referred to the different activities that their colleagues had organized for the Green Day.

They also talked to the university communication department so that all the information related to the Green Day could appear on the different digital and social platforms of the university. In order that every student at university participates in this experience, they contacted the different delegates of each course and degree. Finally, they took photos of all the activities that were published in the blog of the Sustainable Improvement research group $^{1}$.

\footnotetext{
${ }^{1}$ https://tecnundoi.wordpress.com/2016/11/03/comunicado-estudiantil-dia-verde28-de-octubre/
} 


\subsection{Sponsors}

As organizers of getting sponsors, this group of seven students contacted a total of 19 companies. In exchange, they gave them the possibility of giving their company visibility on posters, brochures and in the workshops. The sponsors were in charge of providing prizes for increasing the level of participation in different activities. They contacted a total of 19 companies and organizers only had a positive response from 4 companies. The prizes were: 3 lots of products from Organic49, an ecological supermarket; a batch of Carrefour Express products; a dinner for two in the restaurant Munto Berri; and 10 tickets to the San Sebastian Aquarium. The two first sponsors' products were used as prizes of the different workshops, whereas the dinner and tickets for the Aquarium were raffled between the bicycle participants or people that bought tickets at the flea market.

\subsection{Flea Market}

The eleven students of this group were in charge of organizing a green market, with the aim of collecting second-hand items, selling them to give them a new use annnd encourage a sustainable behavior among the students. For this and throughout the week, they informed through posters and images on the Tecnun screens this activity, asking for students and workers collaboration bringing objects that they were not using anymore. They placed two large cardboard boxes at the entrance of the main building, where they could deposit everything they brought. They could bring anything except clothes as they found it more difficult to sell it among students and teachers of the School. The social objective of the flea market was to raise money to give it to the refugees through an NGO association. They were aware that everything was not going to be sold, so it was decided that the objects that were not sold would go to Caritas.

In addition, organizers decided to sell tickets for a raffle (the same as the bicycle participants) for a cost of one euro. Early in the green day morning, several students were in charge of setting up the tables and placing all the objects collected on them. A total of four tables were needed to place all the objects. Once the objects were placed, they were priced. They also asked the finance department $€ 20$ in $€ 1$ and $€ 0.50$ coins to have changes.

Tickets were also very successful. Along with the objects, 223 euros were collected. Not only students but also employees participated in the flea market. The general impression was that the bags were the least successful objects. On the other hand, the fountain pens had a great level of acceptance as they were in very good condition and were very original. 


\subsection{Workshops}

Three different workshops were prepared: recycling paper, designing a more eco-friendly campus, designing objects with plastic bottles. Around 30 people participated in the workshops. Regarding the activity of recycling paper, the process was as follows. First, they cut the paper into small pieces and put all the paper in a bucket of water. The participants mixed it with the hand, and then they made a dough with the mixer. After this, they distributed the dough obtained in another bucket that contained water and they remixed everything with their hands. Each team took one pair of frames and placed the one that had no grate on top of the other, leaving the grate in the middle. The frame was put into the bucket and a layer of dough was placed inside the box of frames, and then the water was drained out, pressing the hands over the dough. Once they had removed most of the water, they removed the frame without a grid, placed a piece of a t-shirt on the paper, and on a wooden plank. After turning the whole (as if from a potato omelete it was) they repeated the process on the other side. Before plugging one of the sides of the paper with the cloth and board, each team took some tree leaves and put them on the recycled paper obtained and decorated it. Once the paper was covered, a person was placed on top to get it flattened and waited a while. In order to choose the winners of the group, the homogeneity of the mass and the decoration was valued (Figure 2a).
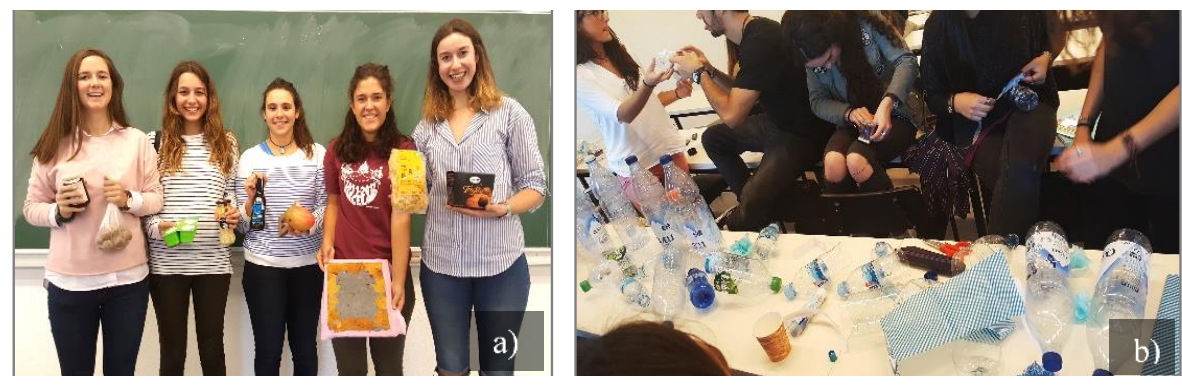

Figure 2. a) Recycling paper activity winners, b) Students designing objects with plastic bottles

The second workshop consisted of thinking about what we would change from the campus to make it more eco-friendly in the future, in 2050. For this activity, they used a Design and Creativity technique called Nominal Group Technique (NGT). This technique is an alternative of brainstorming (Sample, 1984), consequently, the students proposed ideas like Electric cars, renewable energy use, organic garden, use of ecological materials, more green spaces, natural light, and more training related to sustainability.

Regarding workshop 3, they thought of making gift packages and purses/cases with used plastic bottles. To get the materials they did a collection of bottles on the campus and they designed a poster to leave their used plastic bottles in a cardboard box that they placed at the entrance of the main building (Figure 2b). The zippers and decorations (bow, tissue 
paper, stickers) they were bought, and the glue to paste everything was borrowed from university, as well as the scissors to cut all the materials. Most people preferred to make cases/purses rather than gift boxes, as it was more useful. It was amazing how people, even with few materials managed to create different objects, creative, colorful and very useful at the same time.

At the end of the workshops, there were 3 lots of products made of Carrefour Express and Organic 49 products to be handed to each of the winners of the different workshops.

\subsection{Students satisfaction with the Green Day}

At the end of the Green Day, the students' organizers (41) answered a satisfaction survey with the aim to assess on a scale from 1 to 5 the general impressions and knowledge acquired with the Green Day. Fortunately, the students had a positive feeling in average; they especially assigned high scores to the question related to the social skills they could develop with their own partners and friends and an important majority feels comfortable to develop and participate in new activities related to the environmental awareness. On the other hand, students expressed some reservations regarding the sustainability improvement on campus in short and long term.

\begin{tabular}{|c|c|c|}
\hline Item & Question & Score \\
\hline 1. & $\begin{array}{l}\text { I believe that the activity carried out has given me the knowledge and } \\
\text { confidence necessary to participate in other activities aimed at sustainability } \\
\text { and environmental improvement. }\end{array}$ & 3,41 \\
\hline 2. & $\begin{array}{l}\text { I believe that the activity I have done has been useful in learning } \\
\text { environmental sustainability issues. }\end{array}$ & 3,41 \\
\hline 3. & The approach of this activity has been agile, dynamic and effective. & 3,73 \\
\hline 4. & $\begin{array}{l}\text { I believe that the activity carried out will make it possible to achieve } \\
\text { sustainable (long-term) solutions on campus. }\end{array}$ & 2,83 \\
\hline 5. & $\begin{array}{l}\text { I believe that the practices, techniques, and tools used within the activity have } \\
\text { been adequate. }\end{array}$ & 3,78 \\
\hline 6. & $\begin{array}{l}\text { After doing this activity, I feel able to develop and participate in other } \\
\text { environmental improvement activities. }\end{array}$ & 3,63 \\
\hline 7. & Participation in this activity will improve sustainability on campus. & 2,93 \\
\hline 8. & Participation in this course will allow me to improve my skills. & 3,22 \\
\hline 9. & $\begin{array}{l}\text { Participation in this course will help sensitize students to environmental } \\
\text { sustainability. }\end{array}$ & 3,17 \\
\hline 10. & $\begin{array}{l}\text { Participation in this activity will help me in my professional and personal } \\
\text { development. }\end{array}$ & 3,17 \\
\hline 11. & I think the organization of the event has been clear and easy. & 3,63 \\
\hline 12. & $\begin{array}{l}\text { I believe that the activity carried out will help me to improve the good } \\
\text { atmosphere among my colleagues. }\end{array}$ & 3,80 \\
\hline 13. & I think my colleagues see this activity as something positive. & 3,88 \\
\hline 14. & It seems to me positive that more partners participate in this activity. & 4,17 \\
\hline 15. & In general, I am satisfied with this course. & 3,71 \\
\hline
\end{tabular}




\section{Conclusion}

All the organized activities were useful and innovative in the university, as they increase the environmental awareness of students a the campus and as a professional skill. In addition, the green day activities are alternatives to reduce pollution in the environment and proved that it is not very complicated to carry them out. Coming by bike or car sharing does not require any incredible effort. Using waste materials to create new products is an activity that can be carried out by all at our homes. And resell products that are no longer used in the flea market to minimize waste proved that both parties benefit from the sale.

If we continue this way and every year the outdoors activities are improved and even a new one is added, the participation will increase and the impact will be greater both in the students and in the teachers of the school. Consequently, some students have developed their environmental awareness through real actions, instead of traditional courses, and university lecturers had the opportunity to innovate in the way they teach the applications of sustainability and circular economy. The Green Day is key to being able to remind the academic community and future professionals, year after year, that we have to improve our behavior according to the role we have and the quality of life that we carry because it can affect our environment.

\section{Acknowledgements}

The support of the National Program for Fostering Excellence in Scientific and Technical Research of Spain (No. DPI2015-70832-R) is gratefully acknowledged.

\section{References}

Azapagic, A., Perdan, S., \& Shallcross, D. (2005). How much do engineering students know about sustainable development? The findings of an international survey and possible implications for the engineering curriculum. European Journal of Engineering Education, 30(1), 1-19.

Blumenfeld, P.C., Soloway, E., Marx, R.W., Krajcik, J.S., Guzdial, M., Palincsar, A., 1991. Motivating Project-Based Learning: Sustaining the Doing, Supporting the Learning. Educ. Psychol. 26, 369-398. doi:10.1080/00461520.1991.9653139

Cardona, P., \& Lombardía, P. G. (2005). How to develop leadership competencies. EUNSA.

Goel, S. (2006). Investigations on required core competencies for engineering graduates with reference to the Indian IT industry. European Journal of Engineering Education, 31(5), 607-617. 
IB, 2016. Circular economy now included in IB curriculum [WWW Document]. News. URL http://www.ibo.org/news/news-about-the-ib/circular-economy-now-included-inib-curriculum/ (accessed 1.25.17).

Preston, F., 2012. A Global Redesign? Shaping The Circular Economy-briefing paper. Energy, Environment and Resource Governance, EERG BP

Robèrt, K., Broman, G., Waldron, D., Ny, H., Byggeth, S., Cook, D., Johansson, L., Oldmark, J., Basile, G., Haraldsson, H.V., 2004. Strategic leadership towards sustainability

Sample, J.A., 1984. Nominal group technique: An alternative to brainstorming. Journal of Extension. 2, 1-2.

UN, 1992. United Nations Conference on Environment \& Development Rio de Janerio, Brazil , 3 to 14 June 1992, Reproduction. Rio de Jainero. doi:10.1007/s11671-0089208-3

Vincent, S., 2009. Growth in Environmental Studies and Science Programs, Association for Environmental Studies and Sciences. 